\title{
Rifampicin-induced lichenoid eruptions
}

\author{
Hameed Aboobackar Shahul, ${ }^{1}$ Mohan K Manu, ${ }^{1}$ Aswini Kumar Mohapatra, ${ }^{1}$ \\ Mary Mathew ${ }^{2}$
}

${ }^{1}$ Department of Pulmonary Medicine, Kasturba Medical College, Manipal, Karnataka, India

${ }^{2}$ Department of Pathology, Kasturba Medical College, Manipal, Karnataka, India

\section{Correspondence to}

Dr Mohan K Manu, manumohan73@gmail.com

Accepted 3 October 2014

To cite: Shahul HA,
Manu MK, Mohapatra AK,
et al. BMJ Case Rep
Published online: [please
include Day Month Year]
doi:10.1136/bcr-2013-
202346

\section{DESCRIPTION}

A 65-year-old man presented with generalised pruritic skin lesions of 1 month duration. He had a positive pulmonary tuberculosis smear and was on antituberculosis therapy, which included isoniazid, rifampicin, ethambutol and pyrazinamide, for 1 month. His medical history was otherwise unremarkable. He had no significant skin ailments or allergic tendencies in the past.

General physical examination revealed multiple erythematous, pruritic eruptions over the patient's back (figure 1), anterior chest and arms. Haemogram showed marked peripheral eosinophilia $(26.8 \%)$ with an absolute eosinophil count of 3042. The rest of the routine blood investigations were unremarkable. The patient was HIV and hepatitis B surface antigen negative. Chest radiograph (figure 2) showed right upper zone inhomogeneous opacities. After consulting the dermatologist, punch biopsy of the skin lesion was performed, which revealed hyperkeratosis and acanthosis of the epidermis and dense, diffuse perivascular and interstitial lymphocytic infiltrates along with scattered eosinophils and melanophages in the upper dermis (figure 3), consistent with features of lichenoid drug eruptions.

Antituberculosis therapy, which included a $600 \mathrm{mg}$ daily dosage of rifampicin, was stopped and the lesions healed gradually, following which isoniazid, ethambutol and pyrazinamide were restarted sequentially, to which the patient developed no intolerance. On further starting of sequentially increased doses of rifampicin, fresh lesions reappeared when the daily dosage had reached $300 \mathrm{mg}$. Hence rifampicin was withdrawn and the rest of the drugs were continued. The lesions responded to topical $\beta$-methasone and oral antihistamines, and fresh lesions never reappeared. This was accompanied by normalisation of the

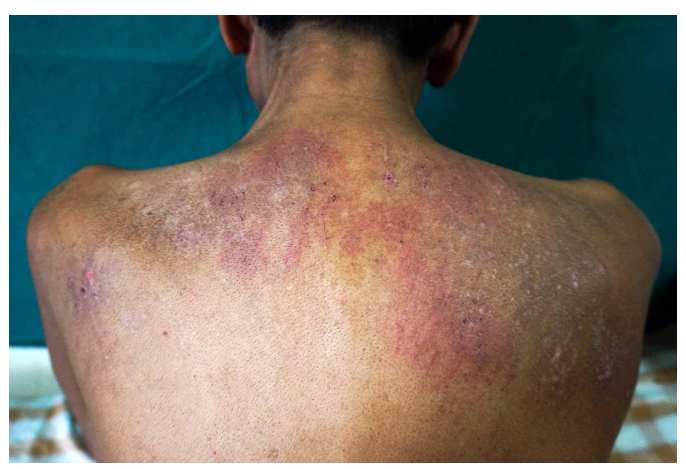

Figure 1 Multiple, extensive erythematous eruptions over the back.

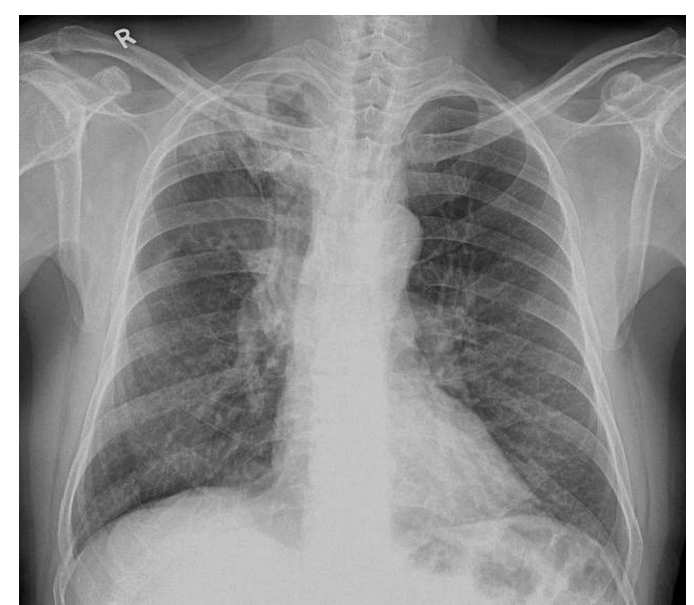

Figure 2 Chest radiograph showing right upper zone inhomogeneous opacities.

peripheral eosinophilia. A diagnosis of rifampicin-induced lichenoid eruptions was established. The patient, during the course of treatment, was found to have multidrug-resistant tuberculosis and was started on kanamycin, levofloxacin, paraamino salicylic acid, linezolid and clarithromycin.

Lichenoid eruptions account for $10 \%$ of cutaneous adverse drug reactions (CADR) during antitubercular therapy. ${ }^{1}$ The incidence rate of rifampicin-induced CADR is about $1.23 \% .^{2}$ However, to the best of our knowledge, reports of rifampicin-induced lichenoid drug eruptions are extremely rare.

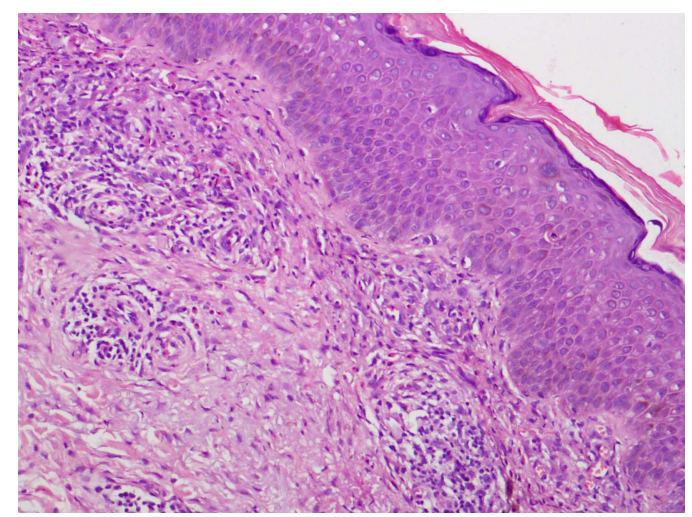

Figure 3 Punch biopsy specimen showing hyperkeratosis and acanthosis of epidermis with dense, diffuse perivascular and interstitial lymphocytic infiltrates along with scattered eosinophils and melanophages in upper dermis (H\&E stain; original magnification $\times 400$ ). 


\section{Learning points}

- Cutaneous adverse drug reactions are common during antitubercular therapy.

- Rifampicin, although rarely, can cause cutaneous adverse drug reactions including lichenoid eruptions.

- Cutaneous adverse drug reactions must be recognised early and intervention initiated to reduce associated morbidity and mortality.
Competing interests None.

Patient consent Obtained.

Provenance and peer review Not commissioned; externally peer reviewed.

\section{REFERENCES}

1 Chakraborty PP, Mondal PC. INH induced lichenoid eruptions. J Assoc Physicians India 2012;60:45.

2 Tan WC, Ong CK, Kang SC, et al. Two years review of cutaneous adverse drug reaction from first line anti-tuberculous drugs. Med J Malaysia 2007;62:143-6.

Copyright 2014 BMJ Publishing Group. All rights reserved. For permission to reuse any of this content visit http://group.bmj.com/group/rights-licensing/permissions.

BMJ Case Report Fellows may re-use this article for personal use and teaching without any further permission.

Become a Fellow of BMJ Case Reports today and you can:

- Submit as many cases as you like

- Enjoy fast sympathetic peer review and rapid publication of accepted articles

- Access all the published articles

- Re-use any of the published material for personal use and teaching without further permission

For information on Institutional Fellowships contact consortiasales@bmjgroup.com

Visit casereports.bmj.com for more articles like this and to become a Fellow 